Павелко О. В. [1; ORCID ID: 0000-0002-2483-2245], к.е.н., доцент

Гарапко Н. I. [2; ORCID ID: 0000-0002-0064-6800], к.е.н., бухгалтер

${ }^{1}$ Національний університет водного господарства та природокористування, м. Рівне ${ }^{2}$ ТзОВ «ЕРАБУС», м. Мукачево

\title{
ОРГАНІЗАЦІЯ АНАЛІТИЧНОГО ЗАБЕЗПЕЧЕННЯ УПРАВЛІННЯ ФІНАНСОВИМИ РЕЗУЛЬТАТАМИ ОСНОВНОЇ ДІЯЛЬНОСТІ БУДІВЕЛЬНИХ ПІДПРИЕМСТВ
}

У статті досліджено етапи аналітичної роботи в частині фінансових результатів основної діяльності будівельних підприємств. Наведено характеристику кожного 3 них. Ідентифіковано завдання організації аналізу фінансових результатів будівельних підприємств. Окреслено принципи організації економічного аналізу. Висвітлено особливості розподілу обов'язків між суб'єктами економічного аналізу фінансових результатів будівельних підприємств. Сформовано основні джерела інформації для аналізу витрат і доходів, фінансових результатів основної діяльності будівельних підприємств.

Ключові слова: будівництво; облік; будівельне підприємство; організація аналізу; фінансові результати; аналітичне забезпечення; основна діяльність; доходи; витрати.

Актуальність теми. За даними ДССУ впродовж 2011-2017 рр. будівництво загалом було збитковим. Втім, вже у 2018 р. будівельна галузь звітує про прибуток в сумі 4414074,1 млн грн. Рівень рентабельності становить лише $2,8 \%$, що значно нижче від середнього показника у вітчизняній економіці (8,1\%). У будівельній галузі в 2018 р. працювало 179 тис. штатних працівників. Частка великих підприємств становила 6,6\%, середніх - 44,4\%, малих 49,0\%. Наведені дані свідчать про наявні у будівництві невикористані резерви, які можуть вплинути на обсяг прибутку в майбутньому. Важливу роль у процесі їх пошуку виконує аналітична система.

Ефективність розроблюваних заходів з максимізації прибутку будівельних підприємств значною мірою залежить від обсягу і якості економічної інформації. Як зазначає Дж. О'Шоннессі, інформація сприяє зниженню невизначеності при прийнятті рішення, але не ліквідує ії. Організація повинна пристосовуватися до низки обмежень через наявність різних точок зору та інтересів тих, хто 148 
задіяний у процесі прийняття рішень; невизначеність зовнішнього середовища і складнощі в зборі, накопиченні й обробці інформації [1, С. 173]. М.Р.Байе вважає, що асиметрична інформація у споживачів і у компаній може також вплинути на розмір прибутку цих компаній [2, С. 529]. Мінімізація рівня асиметрії аналітичної інформації можлива лише за умови якісної організації аналітичної роботи будівельного підприємства. Нині проблеми аналізу фінансових результатів основної діяльності вітчизняних будівельних підприємств теоретично, методологічно й організаційно залишаються розв'язаними лише частково. Це свідчить про актуальність теми дослідження і потребує системного наукового вирішення.

Аналіз останніх досліджень і публікацій. Опрацювання теоретико-практичних засад організації аналізу спостерігається в численних публікаціях вітчизняних науковців, зокрема таких, як: І. А. Бігдан [3], І. В. Замула [4], Т. М. Ковальчук [5], А. М. Кузьмінський [6], Г.І. Купалова [7], І. Д. Лазаришина [8], М. М. Матієшин [9], Є. В. Мних [10], С. 3. Мошенський [11], І. М. Парасій-Вергуненко [12], М. Г. Чумаченко [13] та ін. Однак, незважаючи на суттєвий внесок перелічених вище вчених у розвиток базових аспектів аналізу, значна частка праць за окресленою тематикою має вузькоспеціалізований характер: недостатньо ґрунтовно висвітлено питання організації аналізу фінансових результатів, малодослідженими залишаються питання аналізу фінансових результатів основної діяльності будівельних підприємств.

Постановка завдання. Мета дослідження полягає в ідентифікації етапів аналітичної роботи в частині фінансових результатів основної діяльності будівельних підприємств та характеристиці кожного із них; окресленні принципів організації економічного аналізу; висвітленні особливостей розподілу обов'язків між суб'єктами економічного аналізу фінансових результатів будівельних підприємств.

Викладення основного матеріалу. Підвищення ефективності вітчизняної економіки значною мірою залежить від стабільної позитивної динаміки розвитку будівництва, що потребує поліпшення інвестиційного клімату. Для залучення додаткових інвестицій необхідно сформувати достовірну та оперативну інформаційну базу про фінансові результати суб'єктів господарювання як основу прийняття рішень різними інвесторами.

Наявність аналітичної інформації, що формується задля безперервного процесу управління фінансовими результатами 
будівельних підприємств, повинна супроводжувати весь процес прийняття та реалізації управлінських рішень. Їх аналітичне обґрунтування та оцінка реалізації мають ґрунтуватися на єдиній інформаційній базі. Досягнення поставленого результату, зокрема максимізації фінансових результатів, потребує передусім підвищення зацікавленості працівників та їх вмотивованості.

Організація економічного аналізу - це система заходів щодо дослідження економічних явищ і процесів діяльності суб'єктів господарювання. Водночас це система раціональних дій в процесі вивчення певного об'єкта відповідно до поставлених завдань. 3 одного боку, це система, а з іншого - процес управління економічним аналізом [5]. І. М. Парасій-Вергуненко характеризує організацію як систему раціональних скоординованих дій у процесі вивчення об'єкта спостереження відповідно до визначених завдань [12, С. 42]. Г.І.Купалова під організацією економічного аналізу розуміє систему заходів із забезпечення ефективності, організованості, планомірності, обдуманого упорядкування дослідження об'єкта, а також дотримання внутрішньої дисципліни [7, С. 101]. Ефективність прийнятих управлінських рішень суттєво підвищується за умови чіткої організації економічного аналізу. Мова йде про систему скоординованих дій, а також сукупність заходів із забезпечення їх ефективності, організованості, планомірності, обдуманого впорядкування в частині дослідження доходів, витрат та фінансових результатів згідно з поставленою метою.

Мета організації економічного аналізу фінансових результатів полягає в утворенні системи інформаційно-аналітичних потоків для забезпечення прийняття раціональних управлінських рішень щодо максимізації фінансових результатів діяльності. Для раціональної організації економічного аналізу фінансових результатів необхідно врахувати вимоги, спрямовані на підвищення його ефективності, а саме : плановості, науковості, економічності, динамічності і гнучкості форм аналізу, належного окреслення складу виконавців аналізу, забезпеченості кваліфікованими працівниками, організації робочого місця аналітика. Окремі з них М. М. Матієшин [9] вважає принципами організації економічного аналізу, зокрема такі, як:

- науковості (аналіз повинен носити науковий характер, тобто базуватися на використанні передового досвіду та новітніх методів дослідження);

- системності (створюються умови для дослідження економічних явищ i процесів як складних динамічних систем із 
функціонально-структурною будовою елементів, певним способом пов'язаних між собою та зовнішнім середовищем);

- комплексності (аналітичними процедурами мають охоплюватися всі сторони діяльності підприємства для з'ясування його фінансового стану й ідентифікації необхідних заходів щодо поліпшення його функціонування);

- періодичності (систематичне проведення аналітичних досліджень на основі високої їх організації);

- достовірності (аналіз базується на достовірній, перевіреній інформації, що реально відображає об'єктивну дійсність, а його висновки мають обґрунтовуватися точними аналітичними розрахунками);

- оперативності (аналіз здійснюється швидко і своєчасно, що дасть змогу керівництву будівельного підприємства приймати обґрунтовані управлінські рішення відповідно до поточної кон'юнктури фінансового ринку й пріоритетам розвитку підприємства);

- дієвості (ефективно впливає на діяльність підприємства і його результати, забезпечується вчасне виявлення недоліків у роботі, інформується про це керівництво підприємства, а також попереджається виникнення їх у майбутньому. Результати аналізу мають слугувати для керівництва будівельного підприємства інформаційною базою);

- ефективності (витрати на проведення аналітичного дослідження повинні бути нижчими за оптимальної глибини аналізу і його комплексності);

- всебічності (передбачає врахування всіх внутрішніх зв'язків і відносин системи та всіх факторів, які впливають на їі функціонування);

- динамічності (всі характеристики системи слід розглядати не як постійні, а як такі, що змінюються до своєї протилежності. Принцип динамічності передбачає досить гнучкі зв'язки всередині підприємства між його функціональними підрозділами для здійснення аналізу);

- паралелізму (обов'язкова наявність систем (підсистем) аналізу в усіх самостійних господарських підрозділах).

Мета організації економічного аналізу реалізовується через завдання. Завдання організації аналізу фінансових результатів будівельних підприємств показано на рис. 1. 


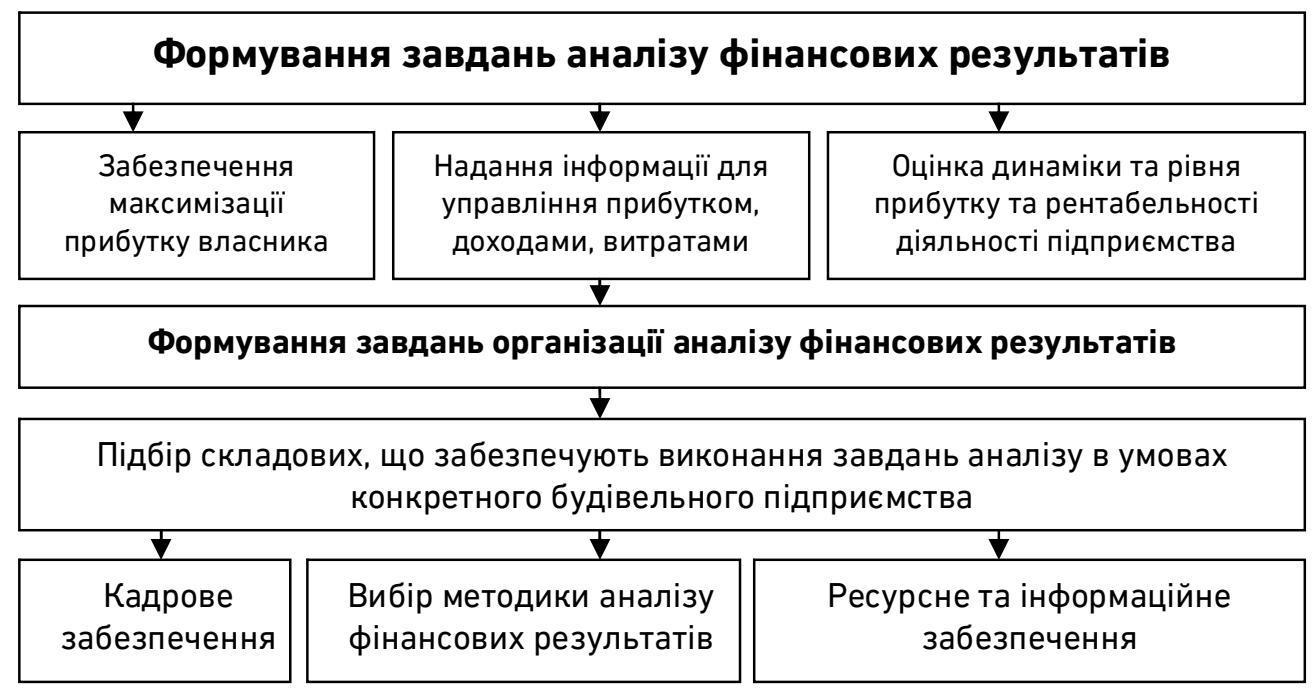

Рис. 1. Завдання організації аналізу фінансових результатів будівельних підприємств*

* Розроблено авторами за даними: [3, С. 19]

Організацію аналізу фінансових результатів на підприємстві слід здійснювати за такими етапами: вибір об'єктів і організаційних форм аналітичного дослідження, розподіл обов'язків між окремими дослідниками; планування аналізу фінансових результатів; інформаційне і методичне забезпечення економічного аналізу фінансових результатів; аналітичне опрацювання даних про хід і результати господарювання; узагальнення результатів аналізу фінансових результатів [4, С. 14; 11].

Є. В. Мних та Н.С.Барабаш організацію аналітичної роботи пропонують здійснювати за такими етапами: підготовчим; основним; завершальним. До підготовчого етапу ними віднесено: розроблення плану і програми аналітичної роботи, формування цілей і завдань фінансового аналізу, розроблення системи показників для характеристики об'єкта аналізу, розроблення макетів і форм аналітичних таблиць, графіків, схем, перевірку достовірності джерел інформації та вивчення матеріалів попередніх обстежень, визначення конкретних виконавців та розподіл обов'язків між ними [10].

Дещо ширше розглядає зміст підготовчого етапу аналізу І. М. Парасій-Вергуненко. Крім наведених операцій і процедур, вона вважає обов'язковими елементами цього етапу також: визначення завдань і об'єктів аналізу, складання графіка проведення аналізу, вибір організаційної форми та розподіл обов'язків між окремими 
виконавцями, збір цифрової та іншої інформації про об'єкт дослідження, перевірку достовірності джерел інформації, ознайомлення з матеріалами попередніх досліджень [12, C. 44].

3 нашої точки зору в розрізі підготовчого етапу слід виокремлювати такі завдання, як: визначення завдань і об'єктів аналізу; планування аналітичної роботи; визначення суб'єктів аналізу, вибір організаційної форми та розподіл обов'язків між окремими виконавцями; інформаційне та методичне забезпечення економічного аналізу, розробка системи показників, що характеризують об'єкт аналізу, побудова макетів аналітичних таблиць, графіків, схем, перевірка достовірності джерел інформації, ознайомлення 3 матеріалами попередніх досліджень; інші організаційні питання.

Мета підготовчого етапу організації економічного аналізу фінансових результатів полягає в створенні сприятливих умов для належної його організації, що включає низку методичних та організаційних аспектів планування аналітичної роботи. Серед аспектів планування аналітичної роботи варто виділити такі: обґрунтування завдань, об'єкта, предмета, користувачів; складання плану аналітичної роботи; формування методичного, інформаційного, матеріально-технічного забезпечення аналізу.

Аналітична робота на будівельному підприємстві, передусім, розпочинається з планування, що передбачає розробку загального плану (складається на тривалий період часу; визначаються об'єкти аналізу, періодичність його проведення, перелік виконавців, джерела інформаціі) та плану конкретних аналітичних робіт (ідентифікуються етапи аналізу, конкретизуються завдання та відповідальні виконавці).

Форми організації економічного аналізу фінансових результатів обумовлюються наявним апаратом управління і технічним забезпеченням на будівельному підприємстві. Найбільш широкого поширення набули централізована (передбачається створення окремого аналітичного відділу, що гарантує єдність методичного забезпечення аналізу, забезпечує розмежування функцій між працівниками і використання спеціального програмного інструментарію для проведення аналізу) та децентралізована форми (передбачається проведення аналізу працівниками різних функціональних підрозділів залежно від рівня їх фаховості та компетенції).

Централізована форма організації економічного аналізу характерна для середніх і великих будівельних підприємств. Якщо 
будівельне підприємство є суб'єктом малого підприємництва, то йому притаманна саме децентралізована форма організації економічного аналізу, оскільки немає потреби в утворенні окремої аналітичної служби задля аналізу фінансових результатів чи інших об'єктів дослідження. Опрацюванням інформації займаються працівниками різних структурних підрозділів залежно від поставлених завдань. За таких умов актуалізується проведення аналізу за матричним підходом, сутність якого обґрунтовано у попередніх підрозділах даного дослідження. Характерна перевага децентралізованої системи - максимальна наближеність до управлінського процесу, що $\epsilon$ сприятливою передумовою для підвищення ефективності здійснюваної аналітичної роботи, а також можливістю застосування персональних комп'ютерів. Аналітичні роботи у цьому випадку розподіляються в існуючій організаційній системі управління підприємством [5, С. 451].

Чисельність і рівень кваліфікації осіб, які здійснюють аналіз, залежить від плану та програми аналізу, а також терміну його здійснення. Розподіл обов'язків між працівниками, що проводять аналіз, доцільно здійснювати, виходячи із розміру підприємства, організаційної структури, забезпечення технічними засобами. Поряд 3 цим, виконання завдань економічного аналізу фінансових результатів вимагає проведення аналітичної роботи всіма відділами підприємства. За рахунок залучення до аналізу працівників, які мають різні знання з питань, що досліджуються, можна досконало дослідити проблему та знайти оптимальні рішення [4, С. 14].

Розподіл обов'язків між окремими підрозділами будівельного підприємства щодо виконання аналітичних робіт передбачається внутрішніми документами. Його можна подати в такому вигляді (табл. 1).

Таблиця 1

Розподіл обов'язків між суб'єктами економічного аналізу фінансових результатів будівельних підприємств*

\begin{tabular}{|c|c|c|}
\hline $\begin{array}{l}\text { № } \\
3 / \text { ח }\end{array}$ & $\begin{array}{c}\text { Функціональні } \\
\text { підрозділи }\end{array}$ & Види аналітичних робіт \\
\hline 1. & $\begin{array}{c}\text { Планово- } \\
\text { економічний } \\
\text { відділ (відділ } \\
\text { управлінського } \\
\text { обліку) }\end{array}$ & $\begin{array}{l}\text { Формування плану економічного аналізу та контроль за } \\
\text { його виконанням; методичне забезпечення аналізу; } \\
\text { організація й узагальнення результатів комплексного } \\
\text { економічного аналізу діяльності підприємства і його } \\
\text { підрозділів; розроблення заходів за результатами } \\
\text { аналізу; звітування за результатами аналізу } \\
\text { керівництву; аналіз виконання плану прибутку і його } \\
\text { використання; контроль за собівартістю будівельних } \\
\text { робіт }\end{array}$ \\
\hline
\end{tabular}


продовження табл. 1

\begin{tabular}{|c|c|c|}
\hline 2. & $\begin{array}{l}\text { Бухгалтерія } \\
\text { (фінансовий } \\
\text { відділ) }\end{array}$ & $\begin{array}{l}\text { Здійснення оперативного аналізу фінансових } \\
\text { результатів на підставі показників доходів і витрат; } \\
\text { аналіз показників балансу (звіту про фінансовий стан) і } \\
\text { звіту про фінансові результати (звіту про сукупний } \\
\text { дохід); аналіз рентабельності; аналіз використання } \\
\text { прибутку }\end{array}$ \\
\hline 3. & $\begin{array}{c}\text { Відділ } \\
\text { маркетингу }\end{array}$ & $\begin{array}{l}\text { Вивчення замовлень; аналіз виконання договірних } \\
\text { зобов'язань, } \\
\text { програми реалізації будівельних робіт; контроль стану } \\
\text { складських запасів; проведення досліджень попиту та } \\
\text { пропозиції на ринку виконання будівельних робіт; } \\
\text { аналіз потенційних можливостей зростання обсягів } \\
\text { будівництва }\end{array}$ \\
\hline 4. & Відділ кадрів & $\begin{array}{l}\text { Оцінювання забезпеченості будівельного підприємства } \\
\text { робочою силою; аналіз якості та руху кадрів; } \\
\text { удосконалення рівня організації праці та підвищення } \\
\text { продуктивності праці; аналіз використання робочого } \\
\text { часу; аналіз витрат фонду заробітної плати; оцінка } \\
\text { ефективності форм і систем оплати праці і } \\
\text { стимулювання праці }\end{array}$ \\
\hline 5. & $\begin{array}{l}\text { Відділ } \\
\text { капітального } \\
\text { будівництва }\end{array}$ & $\begin{array}{l}\text { Аналіз виконання обсягів будівельних робіт; аналіз } \\
\text { витрачання будівельних матеріалів; контроль за } \\
\text { дотриманням технологій; оцінювання інвестиційної } \\
\text { привабливості будівельного підприємства та } \\
\text { потенційного залучення капіталу від інвесторів } \\
\end{array}$ \\
\hline 6. & $\begin{array}{c}\text { Відділ } \\
\text { постачання }\end{array}$ & $\begin{array}{l}\text { Оцінювання виконання плану постачання матеріальних } \\
\text { ресурсів; аналіз кон'юнктури ринку; аналіз стану } \\
\text { складського господарства }\end{array}$ \\
\hline 7. & $\begin{array}{c}\text { Відділ головного } \\
\text { механіка }\end{array}$ & $\begin{array}{l}\text { Аналіз використання наявних потужностей, аналіз } \\
\text { технічного стану (зносу) будівельних машин і } \\
\text { механізмів; розроблення заходів щодо модернізації } \\
\text { наявних основних засобів; оцінювання ефективності } \\
\text { витрачання енергетичних ресурсів }\end{array}$ \\
\hline 8. & $\begin{array}{c}\text { Юридичний } \\
\text { відділ }\end{array}$ & $\begin{array}{l}\text { Розгляд претензійних вимог, аналіз висунутих } \\
\text { штрафних санкцій, які впливають на величину } \\
\text { фінансових результатів }\end{array}$ \\
\hline 9. & $\begin{array}{l}\text { Відділ } \\
\text { технічного } \\
\text { контролю }\end{array}$ & $\begin{array}{l}\text { Аналіз якості будівельних матеріалів, браку, втрат; } \\
\text { розробка заходів щодо мінімізації браку і втрат, } \\
\text { підвищення якості будівельної продукції; дотримання } \\
\text { технологічної дисципліни }\end{array}$ \\
\hline
\end{tabular}

*Розроблено авторами за даними : [4, С. 15; 12, С. 43-44; 13, С. 161-162]

Періодичність проведення економічного аналізу фінансових результатів може бути різною (щомісячно, щоквартально, щорічно) залежно від розміру будівельного підприємства, чисельності працівників, обсягів виконання будівельних робіт тощо. 
Організація економічного аналізу передбачає оптимальний вибір і використання великої кількості різних показників діяльності будь-якого колективу, чого, у свою чергу можна досягнути тільки глибоким вивченням технології, економіки й організації виробництва, стану обліку і звітності, особливостей взаємозв'язків об'єктів економічного аналізу [13, С. 163]. Розробка плану, програми, обрання відповідної методики аналізу $є$ важливими процедурами підготовчого етапу організації економічного аналізу фінансових результатів, які впливають на обсяг та ефективність всієї аналітичної роботи. Ідентифікація інформаційного забезпечення аналізу фінансових результатів, що формується із зовнішніх та внутрішніх джерел інформації також заслуговують на увагу. Аналіз фінансових результатів основної діяльності передбачає аналіз доходів і витрат основної діяльності. Основні джерела інформації, які використовуються при здійсненні такого аналізу будівельних підприємств, наведено у табл. 2, в якій також виокремлено нормативні документи, первинні та зведені документи, регістри обліку, форми фінансової та статистичної звітності.

Окрім основних джерел інформації, при аналізі витрат і доходів діяльності доцільно використовувати статутну і засновницьку документацію, договори про матеріальну відповідальність працівників, накази, висновки за наслідками проведення попередніх перевірок, договори та угоди, укладені із контрагентами, науковотехнічну інформацію (публікації, звіти, технологічну документацію), інформацію про основних контрагентів, дані про стан будівельного ринку.

Як видно з табл. 2, інформація про витрати і доходи будівельних підприємств міститься у двох формах фінансової звітності: формі № 2 «Звіт про фінансові результати» (Звіт про сукупний дохід), у формі № 5 «Примітки до річної фінансової звітності», а також у податковій звітності - «Декларації з податку на прибуток підприємств» та статистичній звітності - Звіті про виконання будівельних робіт (№ 1-кб), Структурному обстеження підприємства (№ 1-підприємництво (річна). Вимоги до складання і подання фінансової звітності визначаються наказами Міністерства фінансів України, податкової звітності - Податковим кодексом України, статистичної звітності - наказами ДССУ. Належна організація на будівельному підприємстві аналізу доходів і витрат основної діяльності має досить важливе значення. Щодо міжнародних стандартів обліку і звітності слід зауважити, що 3 введенням в дію МСФЗ 15 «Дохід від договорів 3 клієнтами» будівельні підприємства, які складають звітність за міжнародними 
стандартами, у своїй діяльності надалі не використовуватимуть норми МСБО 11 «Будівельні контракти» та МСБО 18 «Дохід». МСФЗ 15 «Дохід від договорів з клієнтами» набрав чинності 01 січня 2018 року, замінивши окремі нормативні документи.

Таблиця 2

Основні джерела інформації для аналізу витрат і доходів, фінансових результатів основної діяльності будівельних підприємств*

\begin{tabular}{|c|c|c|}
\hline $\begin{array}{l}\text { № } \\
3 / \pi \\
\end{array}$ & $\begin{array}{c}\text { Види } \\
\text { документів }\end{array}$ & Найменування документів \\
\hline 1. & $\begin{array}{l}\text { Нормативні } \\
\text { документи }\end{array}$ & $\begin{array}{l}\text { - НП(С)БО } 1 \text { «Загальні вимоги до фінансової звітності» від } \\
\text { 07.02.2013 №73; } \\
\text { - П(С)БО } 16 \text { «Витрати» від 31.12.1999 № 318; } \\
\text { - П(С)БО } 15 \text { «Доходи» від 29.11.1999 № 290; } \\
\text { - П(С)БО } 18 \text { «Будівельні контракти» від 28.04.2001 № 205; } \\
\text { - Методичні рекомендації з формування собівартості } \\
\text { будівельно-монтажних робіт від } 31.10 .2010 \text { № } 573 \text { (зі змінами); } \\
\text { - Правила визначення вартості будівництва «ДСТУ Б Д.1.1- } \\
\text { 1:2013 № } 293 \text { від 05.07.2013; } \\
\text { - Національний класифікатор України «Класифікація видів } \\
\text { економічної діяльності ДК 009:2010» від 11.10.2010 № 457; } \\
\text { - Інструкція про застосування Плану рахунків бухгалтерського } \\
\text { обліку активів, капіталу, зобов'язань і господарських операцій } \\
\text { підприємств і організацій від 30.11.1999 № } 291\end{array}$ \\
\hline 2. & $\begin{array}{c}\text { Первинні } \\
\text { документи }\end{array}$ & $\begin{array}{l}\text { - Журнал обліку виконаних робіт (ф. № КБ-6); } \\
\text { - Акт приймання виконаних будівельних робіт (ф.№КБ-2в); } \\
\text { - Лімітно-забірна картка (ф. № М-28); } \\
\text { - Рапорт-наряд про роботу будівельної машини (ф. ЕБМ-4); } \\
\text { - Подорожній лист будівельної машини (ф. ЕБМ-2); } \\
\text { - Розрахунок амортизації основних засобів (ф.№ ОЗ-15); } \\
\text { - Подорожній лист будівельної машини (ЕБМ-3); } \\
\text { - Акт про витрачання давальницьких матеріалів (ф. № М-23); } \\
\text { - Накладна-вимога на внутрішнє переміщення матеріалів; } \\
\text { - Акт інвентаризації незавершеного виробництва (ф. № КБ-7) } \\
\text { тощо }\end{array}$ \\
\hline 3. & $\begin{array}{c}\text { Зведені } \\
\text { документи }\end{array}$ & $\begin{array}{l}\text { - Матеріальний звіт (ф. № М-19); } \\
\text { - Звіт про витрачання основних матеріалів у будівництві } \\
\text { порівняно з виробничими нормами (ф. № М-29) }\end{array}$ \\
\hline 4. & $\begin{array}{c}\text { Регістри } \\
\text { обліку }\end{array}$ & $\begin{array}{l}\text { - Журнал-ордер } 5 \text { (Журнал 5); } \\
\text { - Журнал-ордер } 6 \text { (Журнал 6); } \\
\text { - Відомості та витяги із Головної книги за рахунками 13, 20, } \\
\text { 23, 90, 91, 36, 70, 79; } \\
\text { - Картки рахунків та аналізи рахунків } 13,20,23,90,91,36,70,79 ;\end{array}$ \\
\hline 5. & $\begin{array}{c}\text { Форми } \\
\text { звітності }\end{array}$ & $\begin{array}{l}\text { - Звіт про фінансові результати (про сукупний дохід); } \\
\text { - Примітки до річної фінансової звітності; } \\
\text { - Звіт про виконання будівельних робіт (№ 1-кб); } \\
\text { - Структурне обстеження підприємства (№1-підприємництво } \\
\text { (річна). }\end{array}$ \\
\hline
\end{tabular}

*Розроблено авторами 
Найважливішим з точки зору інформативності $є$ основний етап аналізу, який включає підготовку аналітичних балансів, групування необхідних даних, структурний аналіз, систематизацію й опрацювання необхідної інформації, аналітичну обробку даних про стан і розвиток об'єкта, вивчення напрямів і причин зміни показників, дослідження тенденцій розвитку, з'ясування функціональних зв'язків, розрахунок окремих показників, виявлення взаємозалежних факторів і розрахунок їх впливу на зміну показників, визначення резервів підвищення ефективності діяльності, прогнозування параметрів розвитку досліджуваного об'єкта, ситуаційний аналіз зміни показників діяльності залежно від впливу факторів зовнішнього середовища, оптимізацію існуючих процесів з метою підвищення ефективності діяльності підприємства [12, С. 44-45].

Основними об'єктами організації аналізу є доходи, витрати та фінансові результати. Слід наголосити на доцільності застосування в процесі аналізу методів документального контролю: формальної, арифметичної, перевірки за змістом та зустрічної перевірки. Обов'язково слід перевірити точність арифметичних обчислень, дотримання вимог при заповненні документів, наявність підписів відповідальних осіб, узгодження даних у різних формах звітності, додержання вимог щодо подання звітності до відповідних інстанцій, повноту проведення інвентаризації, якість інформаційних джерел, відповідність облікових і звітних даних реальному стану функціонування господарюючого суб'єкта.

На даному етапі важливо точно окреслити потрібний для проведення аналізу обсяг інформації. Влучно констатує І. В. Замула [4, С. 16], що «...на етапі аналітичної обробки економічної інформації здійснюється побудова аналітичних таблиць, виконується аналіз рядів динаміки, середніх і відносних показників, впливу факторів на результативний показник. За матеріалами аналітичної обробки зібраної інформації здійснюється попередня оцінка доходів, витрат і фінансових результатів. Доцільно дотримуватися таких принципів організації економічного аналізу фінансових результатів, як регламентація (розробка обов'язкового мінімуму таблиць і вихідних форм аналізу для кожного виконавця) та уніфікація (створення типових методик, інструкцій, вихідних форм і таблиць, використання єдиних критеріїв оцінки для всіх виконавців аналізу), що забезпечить порівнянність результатів аналізу, максимальну їх точність, мінімізацію часу на його проведення, спростить підготовку результатів аналітичних перевірок». 
На завершальному етапі здійснюється підсумкове оцінювання діяльності й узагальнення та оформлення отриманих результатів аналітичної роботи, розроблення висновків і пропозицій щодо прийняття відповідних управлінських рішень, необхідних організаційно-технічних заходів, систематичний контроль за виконанням рішень, прийнятих на підставі результатів аналізу [12, C. 45].

Цей етап, безумовно, найбільш відповідальний. Результати проведення аналізу оформляються у вигляді висновків, аналітичних записок (аналітичних висновків) чи звітів (звітів-рапортів), пояснювальних записок та довідок (описова форма), таблиць, рисунків, графіків, схем (безтекстова форма). В структурі аналітичної записки можуть бути виокремлені загальні питання, наведена характеристика виконання плану, подані результати аналізу, представлені висновки і пропозиції. Аналітична записка має більш розлогу форму, аніж довідка і висновок. Описова форма визначення результатів економічного аналізу застосовується для дослідження діяльності будівельних підприємств за тривалий період часу, наприклад, рік, а безтекстова - для проведення оперативного аналізу.

В сучасних умовах проведення аналізу неможливе без використання ЕОМ, що підвищує якість аналітичних висновків, дає змогу зекономити час, працю, витрати. Розвиток інформаційнокомунікаційних технологій і комп'ютерної техніки, на думку І. М. Парасій-Вергуненко, відкрив нові можливості цілеспрямованого використання інформації і знань в економіці, виявив резерви прогресивного розвитку [12, С. 49]. На практичну необмеженість можливостей аналізу господарських операцій і рахунків бухгалтерського обліку за умови використання автоматизованих інформаційних систем вказує у дослідженні І.Д.Лазаришина [8, С. 320]. І.В. Замула наголошує, що «..використання спеціальних комп'ютерних програм в процесі здійснення аналізу дасть змогу зекономити час на проведення аналізу, більш повно дослідити вплив факторів на зміну фінансового результату, отримати більш точні розрахунки, вирішити багатовимірні завдання аналізу які неможливо вирішити без застосування засобів комп'ютеризації» [4, С. 16].

Досліджувані в роботі будівельні підприємства практично не використовують спеціалізовані аналітичні програми через недостатність коштів, нерозуміння переваг їх застосування. Доцільно відмітити, що ефективним інструментом аналітичні системи можуть стати лише за умови, якщо користувач досконало володіє знаннями 
обліку і звітності, прийомами та методами економічного аналізу. Потужний розвиток економічного аналізу, поява нових його об'єктів сприяє удосконаленню існуючих програмних аналітичних продуктів та розширенню їх функціональних можливостей.

Серед вітчизняних програмних продуктів, призначених для аналізу, слід виділити «Audit Expert», «Галактика», «Бест-Ф», «АльтФінанси», «Олімп: Фінексперт» та ін. Програма «Audit Expert» як інструмент аналізу фінансових результатів за даними фінансової звітності дозволяє проводити аналіз за власними методиками, забезпечує можливість порівняння ключових фінансових показників 3 даними конкурентів, зокрема лідерів будівельної галузі, забезпечує проведення ретроспективного та перспективного аналізу. 3 використанням програми «Галактика» можливо проводити аналіз фінансового стану підприємства, модифікувати та створювати власні таблиці, оцінювати якісні параметри фінансового стану, проводити ситуаційний аналіз. Програма «Бест-Ф» генерує звіти, які використовуються для факторного аналізу, дозволяє виконувати аналіз прибутку, обсягів виконаних робіт у розрізі замовників. «Альт-Фінанси» дає змогу аналізувати фінансовий стан і фінансові результати за даними фінансової звітності, проводити горизонтальний, вертикальний, факторний, коефіцієнтний аналіз. У програмі «Олімп: Фінексперт» реалізовано можливість використання моделі Дюпона, статистичного прогнозування, моделювання, порівняння фінансового стану різних будівельних підприємств.

Аналіз вітчизняних програмних продуктів, призначених для аналізу свідчить про їх високу ціну, недостатню кількість вбудованих методик та необхідних інструментів, неможливість врахування специфіки окремих видів економічної діяльності, що значною мірою знижує якість аналітичного дослідження. Найбільш оптимальними традиційно вважаються програми, сумісні 3 програмними продуктами, в середовищі яких ведеться бухгалтерський облік. Вони дозволяють врахувати запити управлінців та особливості діяльності конкретного господарюючого суб'єкта, мають адекватну вартість.

Комплексними автоматизованими системами управління основною діяльністю підприємств $€$ такі відомі у світі програмні продукти, як BAAN (США), PLATINUM (США), SCALA (Швеція), MAN/MANX (США), CHAMPION (США) та вітчизняні програми «Олімп» (Укрекспертиза), БОС (АйТі). Програмне забезпечення подібних продуктів обов'язково включає спеціальні модулі та підсистеми, що забезпечують підтримку управління економікою підприємств [12, С. 50]. Дані обліку будівельних підприємств, сформовані 3 
використанням різноманітних програмних продуктів, слугують інформаційною базою для аналізу результатів господарської діяльності, що, як правило, здійснюється задля ухвалення рішень, кінцева мета яких - максимізація фінансових результатів.

Висновки і перспективи подальших розвідок. Оптимальна організація економічного аналізу фінансових результатів може бути досягнута шляхом створення уніфікованих методик, які передбачають формування аналітичних таблиць, адаптованих під особливості діяльності будівельних підприємств. Показники таких таблиць повинні містити реальні дані і бути максимально придатними для аналізу, порівняння, узагальнення, систематизації, накопичення необхідної інформації.

Реалізація окреслених вище аналітичних завдань на кожному окремому етапі сприятиме проведенню ефективного економічного аналізу фінансових результатів основної діяльності будівельних підприємств, що дозволить підвищити конкурентоспроможність будівельного підприємства на ринку. 3 огляду на це, на будівельних підприємствах слід приділяти більше уваги організації аналізу для отримання високої достовірності результатів. Зазначене - умова підвищення ефективності управління діяльністю будівельних підприємств.

1. О'Шоннесси Дж. Принципы организации управления фирмой. Москва: МТПресс, 1999. 265 с. 2. Байе М. Р. Управленческая экономика и стратегия бизнеса: учеб. пособие для вузов / пер.с англ. под ред. А. М. Никитина. Москва: ЮНИТИ-ДАНА, 1999. 743 с. 3. Організація обліку : навчально-методичний посібник для самостійного вивчення дисципліни для студентів спеціальності 7.03050901 «Облік і аудит» галузі знань 0305 «Економіка і підприємництво» усіх форм навчання / укл. І. А. Бігдан, Г. М. Фадєєва. Харків: ХІБМ, 2012. 206 с. 4. Замула І. В., Примак Т. С. Організація аналізу фінансових результатів в межах маркетингового дослідження конкурентних переваг. Вісник Житомирського державного технологічного університету. Сер. Економічні науки. 2016. № 2. С. 12-19. 5. Ковальчук Т. М. Теорія економічного аналізу: навч. посіб. Черкаси: ЧНУ, 2011. $544 \mathrm{c}$. 6. Кузьмінський А. М., Сопко В. В., Завгородній В.П. Організація бухгалтерського обліку, контролю і аналізу. Київ: Вища школа, 1993. 223 с. 7. Купалова Г. І. Теорія економічного аналізу: навч. посіб. Київ: Знання, 2008. 639 с. 8. Лазаришина І.Д. Економічний аналіз в Україні: історія, методологія, практика: монографія. Рівне: НУВГП, 2005. 369 с. 9. Матієшин М. М. Організація економічного аналізу процесу експлуатації основних засобів у будівельних підприємствах. Ефективна економіка. 2014. № 7. URL: http://nbuv.gov.ua/UJRN/efek_2014_7_47 (дата звернення: 22.05.2020). 10. Мних Є.В. Економічний аналіз: підручник. Київ: Знання, 2011. 630 с. 11. Мошенський С. 3., Олійник О. В. Економічний аналіз : підруч. / за ред. Ф.Ф.Бутинця. Житомир: ПП «Рута», 2007. 704 с. 12. Парасій-Вергуненко І. М. Аналіз господарської діяльності : підруч. / за ред. Л. М. Кіндрацької. Київ : КНЕУ, 2016. 629 с. 13. Болюх М. А., Бурчевський В. З. Економічний аналіз: навч. посіб. / за ред. М. Г. Чумаченка. Київ : КНЕУ, 2001. 540 с. 


\section{REFERENCES:}

1. 0'SHonnessi Dj. Printsipyi organizatsii upravleniya firmoy. Moskva : MTPress, 1999. 265 s. 2. Baye M. R. Upravlencheskaya ekonomika i strategiya biznesa : ucheb. posobie dlya vuzov / per.s angl. pod red. A. M. Nikitina. Moskva : YUNITI-DANA, 1999. $743 \mathrm{~s}$. 3. Orhanizatsiia obliku : navchalno-metodychnyi posibnyk dlia samostiinoho vyvchennia dystsypliny dlia studentiv spetsialnosti 7.03050901 «Oblik i audyt» haluzi znan 0305 «Ekonomika i pidpryiemnytstvo» usikh form navchannia / ukl. I. A. Bihdan, H. M. Fadieieva. Kharkiv : KhIBM, 2012. 206 s. 4. Zamula I. V., Prymak T. S. Orhanizatsiia analizu finansovykh rezultativ $v$ mezhakh marketynhovoho doslidzhennia konkurentnykh perevah. Visnyk Zhytomyrskoho derzhavnoho tekhnolohichnoho universytetu. Ser. Ekonomichni nauky. 2016. № 2. S. 12-19. 5. Kovalchuk T. M. Teoriia ekonomichnoho analizu : navch. posib. Cherkasy : ChNU, 2011. 544 s. 6. Kuzminskyi A. M., Sopko V. V., Zavhorodnii V. P. Orhanizatsiia bukhhalterskoho obliku, kontroliu i analizu. Kyiv : Vyshcha shkola, 1993. $223 \mathrm{~s}$. 7. Kupalova H. I. Teoriia ekonomichnoho analizu : navch. posib. Kyiv : Znannia, 2008. 639 s. 8. Lazaryshyna I. D. Ekonomichnyi analiz v Ukraini: istoriia, metodolohiia, praktyka : monohrafiia. Rivne : NUVHP, 2005. 369 s. 9. Matiieshyn M. M. Orhanizatsiia ekonomichnoho analizu protsesu ekspluatatsii osnovnykh zasobiv u budivelnykh pidpryiemstvakh. Efektyvna ekonomika. 2014. № 7. URL: http://nbuv.gov.ua/UJRN/efek_2014_7_47 (data zvernennia: 22.05.2020). 10. Mnykh Ye. V. Ekonomichnyi analiz : pidruchnyk. Kyiv : Znannia, 2011. 630 s. 11. Moshenskyi S. Z., Oliinyk 0. V. Ekonomichnyi analiz : pidruch. / za red. F. F. Butyntsia. Zhytomyr : PP «Ruta», 2007.704 s. 12. Parasii-Verhunenko I. M. Analiz hospodarskoi diialnosti : pidruch. / za red. L. M. Kindratskoi. Kyiv : KNEU, 2016. 629 s. 13. Boliukh M. A., Burchevskyi V. Z. Ekonomichnyi analiz : navch. posib. / za red. M. H. Chumachenka. Kyiv: KNEU, 2001. 540 s.

\section{Pavelko O. V. [1; ORCID ID: 0000-0002-2483-2245], Candidate of Economics (Ph.D.), Associate Professor Harapko N. I. [2; ORCID ID: 0000-0002-0064-6800], Candidate of Economics (Ph.D.), Accountant}

${ }^{1}$ National University of Water and Environmental Engineering, Rivne ${ }^{2}$ «ERABUS», LLC, Mukachevo

\section{ORGANIZATION OF FINANCIAL RESULTS ANALYTICAL PROVISION OF MAIN ACTIVITIES OF CONSTRUCTION COMPANIES}

The article examines the stages of analytical work in terms of financial results of the main activities of construction companies. The preparatory, main and final stages are highlighted. The purpose of the preparatory stage of the organization of financial results economic analysis is to create favorable conditions for its proper organization. Development of a plan, program, selection of appropriate methods of analysis are important procedures of the preparatory stage of the organization of financial results economic analysis. It is established that the frequency of financial results 
economic analysis may be different (monthly, quarterly, annually) depending on the size of the construction company, the number of employees, the volume of construction work.

The main stage of the analysis is the most important from the point of view of informativeness. It includes preparation of analytical balances, grouping of necessary data, structural analysis, systematization and processing of necessary information, analytical data processing. The task of organizing the financial results analysis of construction companies is identified. It is established that it is important to select the components that ensure the performance of analysis tasks in a particular construction company. The main objects of the analysis are income, expenses and financial results. At the final stage the final evaluation of activity and generalization and registration of the received results of analytical work, development of conclusions and offers concerning acceptance of the corresponding administrative decisions, necessary organizational and technical measures, systematic control over execution of the decisions accepted on the basis of analysis results are carried out. The principles of organization of economic analysis are outlined.

The peculiarities of the distribution of responsibilities between the subjects of financial results economic analysis of construction companies are highlighted. The types of analytical work between such departments of the company as: planning and economic department (management accounting department), accounting (finance department), marketing department, personnel department, capital construction department, supply department, chief mechanic department, legal department, technical control department are considered. The main sources of information for the analysis of expenses and incomes, financial results of the main activity of construction companies are formed. It is established that the implementation of the above analytical tasks at each stage will contribute to an effective economic analysis of the financial results of the main activities of construction companies, which will increase the competitiveness of the construction company in the market. Construction companies should pay more attention to the organization of the analysis to obtain high reliability of the results. This is a condition for improving the efficiency of management of construction companies.

Keywords: construction; accounting; construction company; organization of analysis, financial results; analytical support; main activity; income; costs. 
Павелко О. В. [1; ORCID ID: 0000-0002-2483-2245], К.э.Н., доцент

Гарапко Н. И. [2; ORCID ID: 0000-0002-0064-6800], к.э.н., бухгалтер

\author{
${ }^{1}$ Национальный университет водного хозяйства и природопользования, г. Ровно \\ ${ }^{2} 000$ «ЕРАБУС», г. Мукачево
}

\title{
ОРГАНИЗАЦИЯ АНАЛИТИЧЕСКОГО ОБЕСПЕЧЕНИЯ УПРАВЛЕНИЯ ФИНАНСОВЫМИ РЕЗУЛЬТАТАМИ ОСНОВНОЙ ДЕЯТЕЛЬНОСТИ СТРОИТЕЛЬНЫХ КОМПАНИЙ
}

\begin{abstract}
В статье исследованы этапы аналитической работы в части финансовых результатов основной деятельности строительных предприятий. Приведена характеристика каждого из них. Идентифицированы задачи организации анализа финансовых результатов строительных предприятий. Определены принципы организации экономического анализа. Освещены особенности распределения обязанностей между субъектами экономического анализа финансовых результатов строительных компаний. Сформированы основные источники информации для анализа расходов и доходов, финансовых результатов основной деятельности строительных предприятий.

Ключевые слова: строительство; учет; строительное предприятие; организация анализа, финансовые результаты; аналитическое обеспечение; основная деятельность; доходы; расходы.
\end{abstract}

